\title{
A new glandular Mimosa species from Southern Brazil and insights about its glandular trichomes micromorphology
}

\author{
Fernanda Schmidt Silveira* (1), Wanderleia de Vargas ${ }^{2}$ (1), Ana Paula Fortuna-Perez ${ }^{2}$ (1) \\ and Silvia Teresinha Sfoggia Miotto ${ }^{1}$
}

Received: March 31, 2019

Accepted: June 28, 2019

\begin{abstract}
Mimosa baptistae is a new species presenting stalked glandular trichomes that give it a glutinous appearance, mainly with respect to the leaflets. Furthermore, it is an aculeate species, with multijugate leaves, white stamens, and fruits also covered by glandular trichomes. A herbaria survey and fieldwork only recorded this species as occurring on sandstone outcrops of the city Caçapava do Sul, Brazil. The species may be confused with other species of Mimosa sect. Batocaulon ser. Stipellares such as M. bifurca, M. sobralii and M. lepidota. However, features such as absence/presence of aculei, stamens color, habitat, and flower features are useful for distinguishing them from the new species. Here, we provide notes on morphology, geographic distribution, as well as anatomical detail of its glandular trichomes and content. Finally, we discussed the taxonomic significance of the micromorphology of glandular trichomes and their content in Mimosa ser. Stipellares as well as the potential applicability of such features to better understand the morphology of this series.
\end{abstract}

Keywords: glands, leaflets, Pampa, secretory structures, Serra do Sudeste

\section{Introduction}

Mimosa is one of the most diversified genera among angiosperms, with more than 500 species (Bessega et al. 2008; Simon et al. 2011). Most of Mimosa's diversity is found in Brazil, which is the main center of diversity and endemism of the genus (Simon et al. 2011), harboring circa 358 to 366 species (BFG 2015; Flora do Brasil 2020 (under construction) 2018). Furthermore, the diversity of Mimosa not only encompasses species richness, but also morphological and ecological diversity. For example, Mimosa has more trichomes diversity than any other genus of the mimosoid clade (subfamily Mimosoideae in Barneby 1991). In addition, the trichome type is a remarkable feature of many species of Mimosa, and this feature is often reflected in their specific epithets (e.g., Mimosa glanduliseta, $M$. glandulosa, M. lepidota, and M. verrucosa, Santos-Silva et al. 2013).

Since 2006, many new Mimosa species have been described based on differences of its trichomes. For example, M. suberosa is differentiated from other species of Mimosa ser. Piresianae by its indumentum of short glandular setae (Atahuachi \& Hughes 2006). Other example is $M$. myrioglandulosa differing from $M$. maguirei by its stems with sessile glandular trichomes (Dutra \& Garcia 2013b). Additional recently published species, in which indumentum is an important characteristic used to separate taxa, are: $M$. foreroana (Santos-Silva \& Tozzi 2012); M. longistipula (Dutra \& Garcia 2013a), and M. urandiensis (Santos-Silva et al. 2013).

1 Programa de Pós-Graduação em Botânica, Universidade Federal do Rio Grande do Sul, 91501-970, Porto Alegre, RS, Brazil

2 Programa de Pós-Graduação em Botânica, Universidade Estadual Paulista Júlio de Mesquita Filho, 18618-970, Botucatu, SP, Brazil

* Corresponding author: okologie_natur@hotmail.com 
Trichomes in Mimosa can be glandular or non-glandular (Santos-Silva et al. 2013). Glandular trichomes are considered to be derived characteristics in the genus, being classified as sessile or stipitate (Santos-Silva et al. 2013). Recently, Grohar et al. (2016) have classified the stalked glandular trichomes in the Dolentes-Brevipedes complex as globose and clavate according to the head shape and number of cells of the stalk. In addition, glandular trichomes produce, store, and secrete different classes of secondary metabolites that may be associated with different ecological interactions; however, the chemical composition of these secretions is still unknown (Santos-Silva et al. 2013). In this work, we described a new species with glandular trichomes, illustrating them by using anatomical features, scanning electron microscopy and histochemical tests.

\section{Materials and methods}

\section{Taxonomical analysis}

Foreign and Brazilian herbaria were consulted, particularly from South America (BHCB, BOTU, CORD, CESJ, CTES, E, ESA, F, FURB, HAS, HDCF, HPBR, HUCS, HUEM, HURG, HVAT, IAC, ICN, JOI, K, MBM, MO, MPUC, MVM, NY, P, PACA, PEL, R, RB, SJRP, SMDB, SPSF, and USZ (acronyms according to Thiers 2019). However, the new species was recognized only from exsiccates at ICN, HAS, and HDCF herbaria. In addition, field collections were conducted to obtain additional data about flowering, fruiting, geographic distribution of the new species, which was delimited, based on external morphology, micromorphology of trichomes, and ecological constrains.

\section{Anatomical methods}

Samples of dried leaflets of the new species based on Schmidt-Silveira 855 and duplicates of at least two specimens were rehydrated in glycerine and serially dehydrated in ethanol (until $95 \%$ ethanol). Leaflets were embedded in Historesin (Leica), and cross sections were prepared using a rotary microtome. Samples were stained with Toluidine $\mathrm{pH}$ 4.7 (Vidal 1977). Images were obtained using an Olympus digital camera linked to a light microscope in the Laboratory of Plant Anatomy of UNESP, Botucatu, SP, Brazil (LaPAV).

We performed the following histochemical tests on leaflets: Sudan IV (Pearse 1980) for lipids, NADI reagent (David \& Carde 1964) for oleoresins, vanillin hydrochloric (Mace \& Howell 1974) for tannin, ferric chloride (Johansen 1940) for phenolic compounds, Dragendorf (Svendsen \& Verpoort 1983) for alkaloids, and cupric acetate (Ganter \& Jollés 1969) for resin.

In addition, we provide images of the glandular trichomes on the branches and fruits from scanning electron microscopy (SEM) analyses, illustrating that they appear to be sessile trichomes without an anatomical approach.
The samples were submitted to critical point-dried using $\mathrm{CO}_{2}$, mounted on aluminum stubs, coated with gold, and examined using a Quanta 200 (FEI Company) scanning electron microscope at $20 \mathrm{kVat}$ in the Electron Microscopy Centre of the Institute of Bioscience of UNESP, Botucatu, SP, Brazil.

\section{Results}

\section{Taxonomic treatment}

Mimosa baptistae Schmidt-Silveira \& Miotto sp. nov. Type: BRAZIL, Rio Grande do Sul: Caçapava do Sul, estrada para Pedra do Segredo, próximo à Pedra do Leão, 30³2'40.7"S 5332'53.2”W, 240 m elev., 07 Sep 2015 [fl+fr], Schmidt-Silveira, 855 (holotype: ICN isotypes K, MBM, NY). (Figs. 1-3).

Mimosa baptistae is an aculeate species, which has a glutinous foliage, multijugate leaves, leaflets of all pinnae are inserted alternate along pinna-rachis, having diminute leaflets $(1.5-2.6 \times 0.9-1.25 \mathrm{~mm})$, presence of glandular trichomes with obconical head and unisseriate stalk on leaflets; subglobose inflorescence, white stamens; and fruits covered by glandular trichomes.

Shrubs or treelets attaining $2.5-5 \mathrm{~m}$ tall. Branches reddish-brown, cylindrical to subquadrangular with grooves, glabrous, covered with a colorless and bright substance such as a resin, armed with straight or semi-recurved aculei of 3-6 mm long. Leaves bipinnate $20-68 \mathrm{~mm},(4) 5-8(10)$ jugate, pinnae subopposed to alternate of (7)15-28(33) mm long, (8)11-19(25) pairs of leaflets. Spicule present. Paraphyllidia reniform, $0.4-0.5 \times 0.2-0.3 \mathrm{~mm}$, glandular. Petioles developed, 7.5-12(19) mm long, glabrous, with glandular trichomes when young, cylindrical to sulcate. Leaflets oblong, 1.5-2.6 $\times 0.9-1.25 \mathrm{~mm}$, alternate arranged along the pinna, base asymmetric and semi-hastate, apex rounded, apparently veinless in both faces, visible orange-brown punctuations, margin glabrous and smooth, glandular trichomes with obconical head and unisseriate stalk on leaflets, lipid-secreting. Stipules tiny, retrorse, deciduous, brownish, triangular, $0.4-0.8 \times 0.3-0.6 \mathrm{~mm}$, without veins, margin glabrous. Sinflorescence racemose, pseudoracemose or paniculate. Inflorescence capituliform, suglobose with peduncles of (4)9-12 mm long, glabrous and covered with a colorless and bright substance such as a resin. Bracts spatulated, 0.5-0.6 × 0.14-0.19 mm, glabrous, including the margin, before anthesis smaller than corolla. Calyx campanulate, glabrous, glandular, reddish-brown, 0.5-0.65 mm long, covering $1 / 4$ of corolla length. Corolla subtubular or vase-shaped, $2-2.25 \times 0.7-0.9 \mathrm{~mm}$, lobes vinaceous, glandular. Ovary oblong, glabrous, glandular, $0.6-0.8 \mathrm{~mm}$ long, stipite $0.35-0.5 \mathrm{~mm}$ long. Stamens eight, exserted 1.6-3.0 mm long, free, but united below ovary, filaments white. Fruits oblong, plane-compressed, moniliform, covered with a colorless and bright substance 


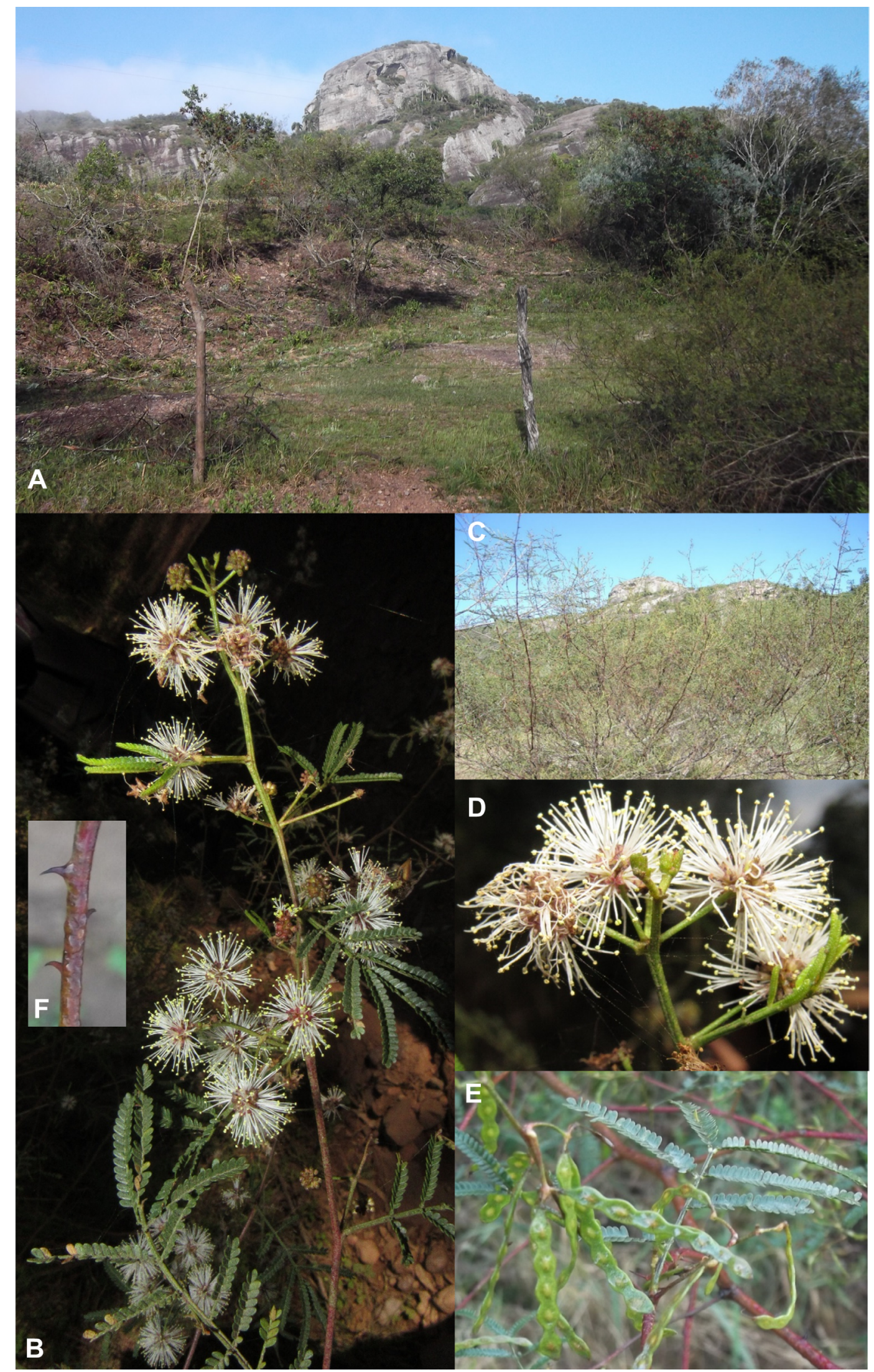

Figure 1. Mimosa baptistae: A. Habitat at Serra do Sudeste, Pampa biome, Brazil. B. Detail of a shrub individual; C. Population density. D. Arrangement of inflorescence, also showing the white stamens. E. Fruits. F. Detail of branches covered by a colorless and bright substance, resembling a resin. (Photos B and D from G.P. Coelho; Photos A, C, E, F from F. Schmidt-Silveira). 

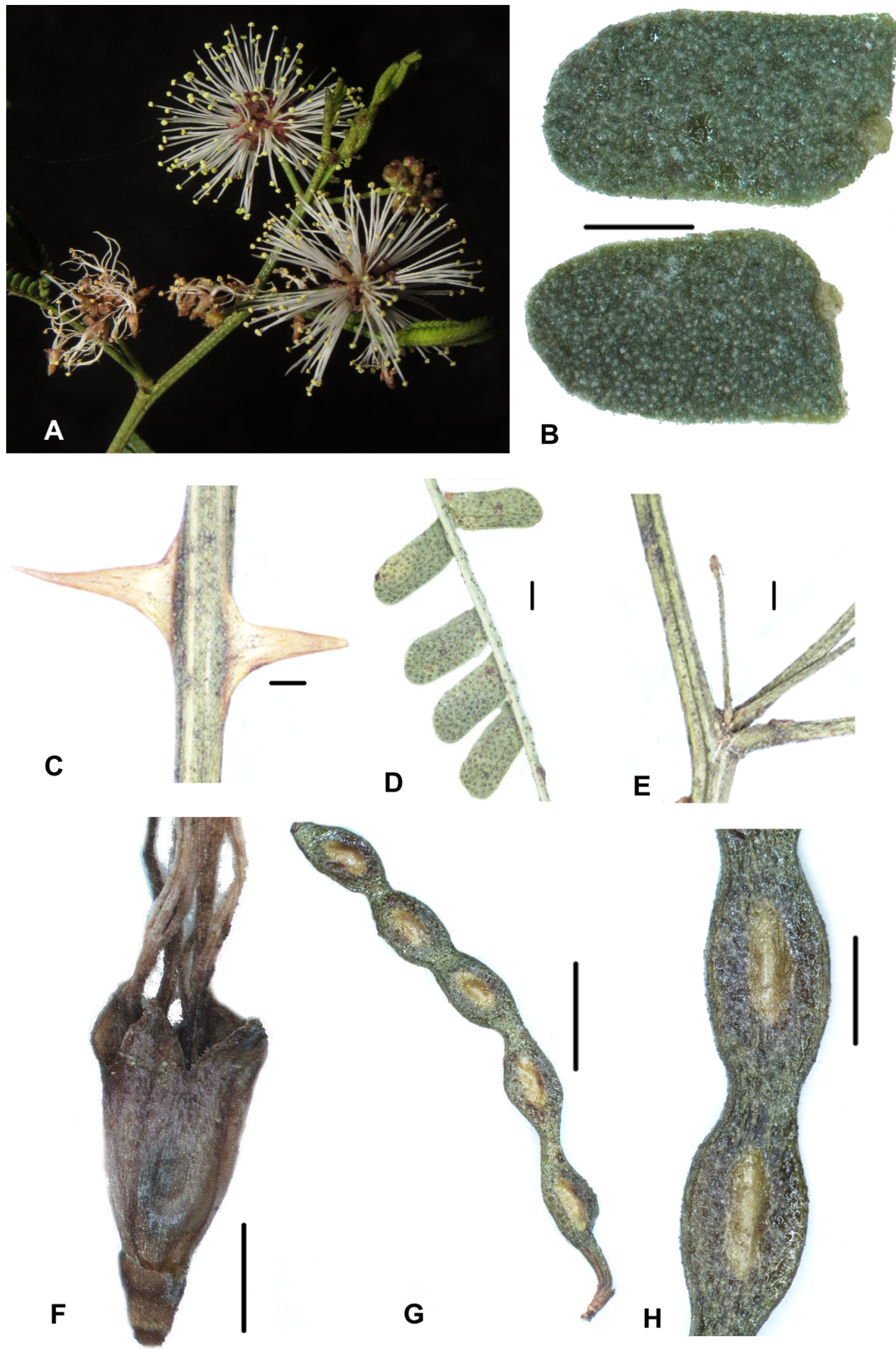

Figure 2. Mimosa baptistae morphological details. A. Capituliform subglobose inflorescence B. Leaflets C. Aculei. D. leaflets punctuations E. Subquadrangular branches with grooves. F. Calyx and corolla G. Fruit. H. Articles covered by a colorless and bright substance, resembling a resin. Scale bars of $1 \mathrm{~mm}$. (A-H from the holotype, photo A from G. P. Coelho; photos B-H from F. Schmidt-Silveira). 


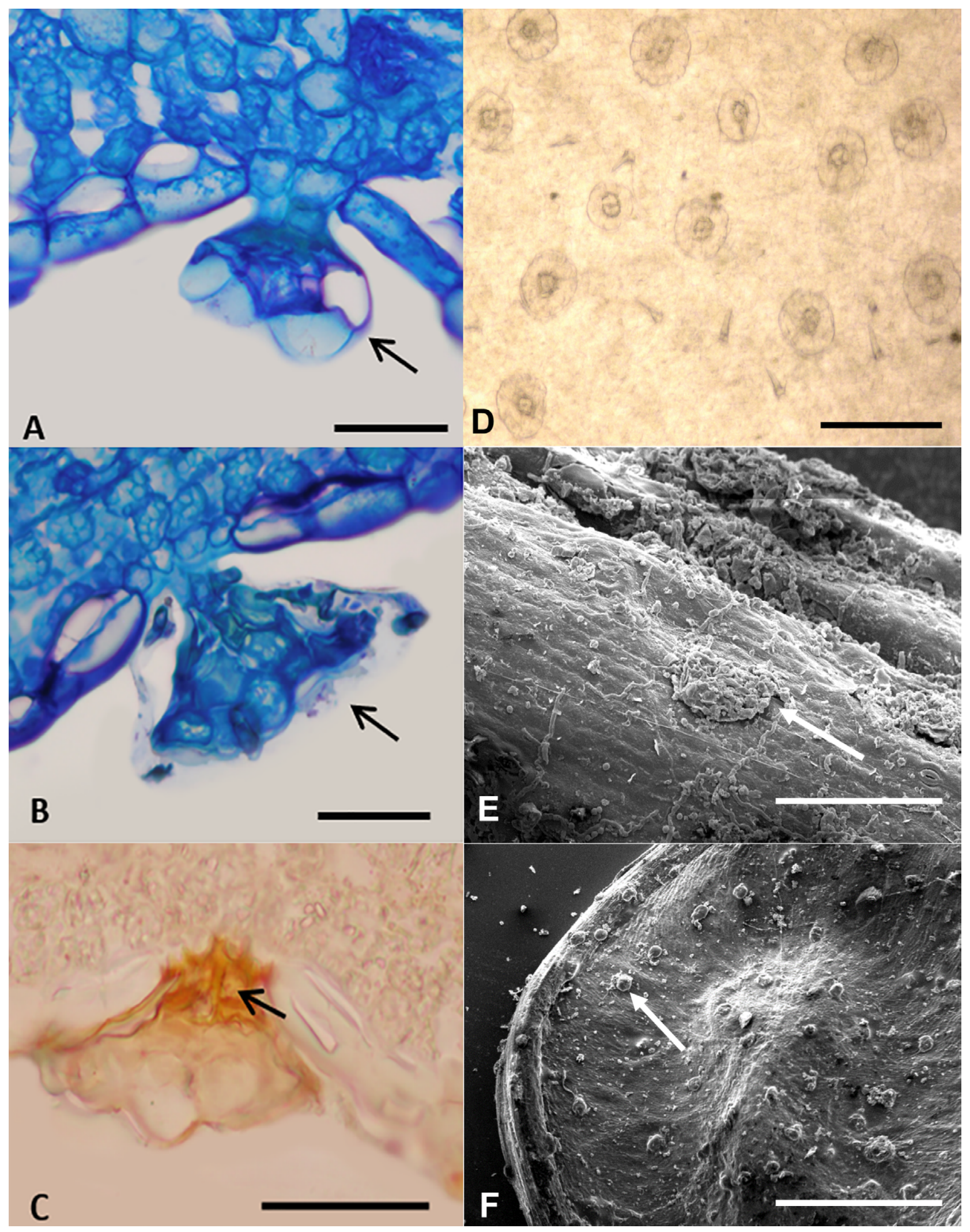

Figure 3. Optical micrographs (A-D) of glandular trichomes on the abaxial surface of Mimosa baptistae and SEM images (E-F). A-B. Glandular trichomes with unisseriate stalk before (A) and after secretion (B) (black arrow). C. Sudan IV positive histochemistry test showing lipids (black arrow). D. Overview of the surface of leaflets treated with sodium hydroxide, showing the glandular trichomes. E. Overview of a branch surface showing glandular trichome (white arrow). F. Glandular trichome on the fruit surface (white arrow). Scale bars: $50 \mu \mathrm{m}$ (A-C); $100 \mu \mathrm{m}$ (D); (E) $200 \mu \mathrm{m}$, (F) $2.0 \mathrm{~mm}$. 
such as a resin, $13-44 \times 2.8-3.5 \mathrm{~mm}$, short-stipitate, $1.7-3.0$ mm long, (1) 3-5(7) articulate, apex cuspidate, valves and replum glabrous and glandular. Seeds immature.

Flowering and fruiting-August-January.

Distribution and ecology-Mimosa baptistae may be considered an endemic species up to now for Caçapava do Sul at the hills of Pedra do Segredo, Pedra do Leão and their neighborhood, in Serra do Sudeste (Rio Grande do Sul State), where it grows on sandstone outcrops, shrublands (vassoural), and rocky grasslands, at approximately 200 to $500 \mathrm{~m}$ elevation. Caçapava do Sul belongs to the physiographic region of Serra do Sudeste (Fortes 1959), which is highlighted as a high-level priority area for conservation (CNCFlora 2014) in the Pampa biome. Furthermore, Pedra do Segredo and Pedra do Leão harbor other species endemic and rare such as Pavonia secreta Grings \& Krapov, Petunia secreta Stehmann \& Semir, Petunia exserta Stehmann, and Croton pygmaeus L.R. Lima (Grings et al. 2011).

Etymology-The specific epithet is in honor of Dr. Luís Rios de Moura Baptista, who studied many groups of plants from the Flora of Rio Grande do Sul, including the Mimosa genus.

Comments-Mimosa baptistae resembles some species of Mimosa section Batocaulon ser. Stipellares such as $M$. bifurca Benth., M. lepidota Herzog, M. sobralii Grings \& Ribas by its glutinous foliage and the alternate insertion of the leaflets. However, the most outstanding external morphological difference among all these species is the presence of aculei only in $M$. baptistae. From $M$. bifurca, the new species also differs by the color of the stamens (white $v s$. pink), as well as its restricted range and habitat (only known to Caçapava do Sul, Brazil vs. widespread in Argentina, Brazil, Paraguay and Uruguay). Whereas M. lepidota inhabits tropical-montane valleys in the Bolivian Andes, at 1800 to $2350 \mathrm{~m}$ altitude, Mimosa baptistae is restricted to low altitudes in subtropical grasslands in Brazil, and it is an armed species with deciduous and non-cochleately stipules besides shorter measures (e.g., peduncles (4) 9-12 mm long vs. $15-30 \mathrm{~mm}$ long; calyx $0.5-0.65 \mathrm{~mm}$ long vs. $1.2-1.4 \mathrm{~mm}$ long). From M. sobralii, $M$. baptistae differs by the white stamens (vs. yellow), longer corolla (2-2.5 mm vs. 1.3-1.5 $\mathrm{mm}$ ), and type of habitat (vassoural and rocky grasslands of Pampa biome vs. forest edges and rocky formations of Araucaria forests in Mata Atlantica biome).

Although M. baptistae seems to be closer to M. intricata Benth. in our adapted key, these species are readily distinguished by the habit (treelets vs. prostrate subshrubs) and color of their stamens (white vs. pink). Nevertheless, we found some exsiccates of $M$. baptistae identified as $M$. intricata. For example, Machado \& Marchiori (2017) showed some wood anatomical features for $M$. baptistae, which was mistakenly identified as $M$. intricata. Nonetheless, their work also supports the circumscription of the new species in Mimosa ser. Stipellares due to the presence of vessels in large clusters, a feature apparently restricted to species of this series (Machado \& Marchiori 2017). On the other hand, Mimosa baptistae may be easily confused as an armed version of Mimosa bifurca when flowers are absent. This similarity to $M$. bifurca has been reported for many other species of Mimosa ser. Stipellares (e.g., M. glycyrrhizoides Barneby and M. sobralii).

Additional specimens examined. BRAZIL. Rio Grande do Sul: Caçapava do Sul, Pedra do Segredo, 07. Sep 2015 [f], F. Schmidt-Silveira 856 (ICN); idem, 00 Jan 1999 [fr], M. Sobral \& J. Larocca 8715 (ICN); idem 00 Aug 1998 [fl], M. Sobral, J. Larocca \& D. Guadagnin 9548 (ICN); idem, 12 Nov 1980 [fr], J. Mattos 21591 (HAS); idem, 15 Aug 1998 [f], S. Bordignon, B. Irgang et al. 1426 (HAS); idem 13 Aug 1986 [fr], J.N.C Marchiori 486 (HDCF); idem 4 Sep 1986 [fr], J.N.C Marchiori 509 (HDCF); 30S36'45.4”, 53W31'32.7”, 408 m elev., 07.09.2015 [fr], F. SchmidtSilveira 857 (ICN).

Key to Mimosa ser. Stipellares with leaflets arranged alternate along the pinna-rachis (adapted from Barneby, 1991).

1. Plants unarmed.

1'. Plants armed with straight aculei...

2. Fruits hispid, forming a unit; inflorescence oblong................................................................................... M. strobiliflora

2'. Fruits glabrous, clearly individualized, not forming a unit; inflorescence globose.................................................. 3

3. Purple or pink stamens; wide range and habitats (from eastern Paraguay through northeastern Argentina to interior Uruguay and Southern Brazil (RS, SC, PR, SP).... M. bifurca

3'. White stamens; restricted range and habitats (see below for more detail)..... $\ldots . .4$

4. Shrubs or trees up to $8 \mathrm{~m}$ tall; plants growing on forest edges and rocky formations on mountain slopes from northeastern Rio Grande do Sul state (Brazil), at 400 to $900 \mathrm{~m}$ altitude..... M. sobralii 4'. Shrubs attaining 2-2.5 m tall; plants growing on woodlands of Tropical-montane valleys in the Bolivian Andes, at 1800 to $2350 \mathrm{~m}$ altitude. M. lepidota

5. Inflorescence spiciform; branches setose, covered by glandular-setulose trichomes M. barnebiana

5'. Inflorescence globose; branches glabrous, covered only by glandular trichomes

6. Pods densely hispid; leaflets 2-3-nerved at dorsal face. M. glycyrrhizoides 
6'. Pods glabrous; leaflets veinless in both faces

7. Prostrate subshrubs; stamens purples; leaflets $1-1.4 \times 0.4-0.8 \mathrm{~mm}$

M. intricata

7'. Shrubs or treelets attaining 2.5-5 m tall; stamens white; leaflets $1.5-2.6 \times 0.9-1.25 \mathrm{~mm}$

M. baptistae

\section{Anatomical and histochemical features}

We only found a morphotype of glandular trichomes in the leaflets of $M$. baptistae, which exhibits an obconical head and unisseriate stalk (Fig. 2A-D). This trichome presents a variable number of cells in the head and stalk with one or two cells in front view, and usually occurs on the abaxial surface of the leaflet. Regarding this characteristic, we classified it as a stipitate trichome. Nevertheless, this trichome morphology in SEM images resembles a sessile trichome (Fig. 2E-F). Furthermore, these glandular trichomes secreted lipids, observed for the Sudan IV histochemistry test (Fig. 2C, Tab.1).

Table 1. Histochemical tests performed with leaflets of Mimosa baptistae.

\begin{tabular}{|c|c|c|}
\hline Histochemistry tests & Compounds & Reaction \\
\hline Cupric acetate & Resins & Negative \\
\hline Dragendorf & Alkaloids & Negative \\
\hline Ferric Chloride & Phenolic Compounds & Negative \\
\hline Nadi reagent & Oleoresins & Negative \\
\hline Sudan IV & Lipids & Positive \\
\hline Vanillin hydrochloric & Tannin & Negative \\
\hline
\end{tabular}

\section{Discussion}

Mimosa baptistae is morphologically related to representatives of Mimosa sect. Batocaulon ser. Stipellares, which is recognized by the dilated paraphyllidia (Barneby 1991) and is considered a monophyletic series referred to as clade $\mathrm{K}$ in the Mimosa phylogeny (Simon et al. 2011). This series has ca. 21 species, occurring in open fields, and is practically restricted to the south of South America distributed in Argentina, Brazil, Paraguay, and Uruguay, except Mimosa lepidota that occurs in valleys of the Bolivian Andes. Furthermore, this series is divided into two circles of affinity based on leaflet distribution along pinna rachis and glandular trichomes, designated as stalked and sessile glands (Barneby 1991). Nevertheless, these affinities were proposed without an anatomical comparative framework of glandular trichomes; such a framework may be useful to support differences among species in this series. Thus, future studies are required to test whether the micromorphology of glandular trichomes would be a useful feature to distinguish species in Mimosa ser. Stipellares.

In Mimosa, trichomes have been used in the revision of taxonomic complexes (e.g., Grohar et al. 2016) and in the description of new taxa, particularly in Mimosa sect. Mimosa (e.g. Morales et al. 2013; Morales \& Fortunato 2013). Furthermore, Santos-Silva et al. (2013) pointed out that trichome morphology in Mimosa offers a set of characteristics that can be used for differentiating species and species groups in combination. However, most of these works have considered only the macromorphological point of view, in other words, only the external morphology of trichomes and without anatomical details. In our work, we showed that Mimosa baptistae has stalked glandular trichomes by micromorphological analyses (optical micrographs), although it appears to have sessile glandular trichomes under a macromorphological view (SEM images). Our results suggest that the sessile or impressed glands described for this group in Mimosa ser. Stipellares should be reviewed concerning the micromorphological view (anatomical analyses) due to these glands being misidentified as sessile glandular trichomes despite being stalked glandular trichomes or not being macromorphologically distinguished (e.g., glandular content). Moreover, these findings may have implications on the delimitation of groups of affinity inside of Mimosa ser. Stipellares.

This study reports for the first time the chemical content of glandular trichomes for the Mimosa genus, showing that this new species secretes a lipophilic substance. However, further research is required to identify the chemical nature of this substance and whether it is the same substance that covers all the structures of Mimosa baptistae. Differences in secretory content have distinct ecological functions and may be a good source for elucidating the diversification in Mimosa ser. Stipellares. Furthermore, secretory structures such as glandular trichomes may synthetize and/or accumulate metabolites of high phytochemical and pharmacological value (Fahn 1979), representing a field still unexplored in Mimosa.

\section{Acknowledgements}

We gratefully acknowledge the Electron Microscopy Center of the Institute of Bioscience of the UNESP (Botucatu) for their assistance with sample preparation and Silvia Rodrigues Machado for suggestions. We also wish to thank Marcos Sobral for his help and Guilherme Peres Coelho for the photos provided, the Department of Zoology UFRGS for allowing the use of photo equipment, and $\mathrm{CNPq}$ for financial support.

\section{References}

Atahuachi MB, Hughes CE. 2006. Two new species of Mimosa (Fabaceae) endemic to Bolivia. Brittonia 58: 59-65.

Barneby RC. 1991. Sensitivae censitae: a description of the genus Mimosa Linnaeus, (Mimosoideae) in the New World. Memoirs of the New York Botanical Garden 65: 1-835.

Bessega C, Hopp HE, Fortunato RH. 2008. Toward a phylogeny of Mimosa (Leguminosae: Mimosoideae): a preliminary analysis of Southern South American species based on chloroplast DNA. Annals of the Missouri Botanical Garden 95: 567-579. 
BFG - The Brazil Flora Group. 2015. Growing knowledge: an overview of Seed Plant diversity in Brazil. Rodriguésia 66: 1085-1113.

CNCFlora - Centro Nacional de Conservação da Flora. 2014. Áreas Prioritárias para conservação e uso sustentável da Flora Brasileira ameaçada de extinção. Rio de Janeiro, Instituto de Pesquisas Jardim Botânico do Rio de Janeiro.

David R, Carde JP. 1964. Coloration differentielle dês inclusion lipidique et terpeniques dês pseudophylles du Pin maritime au moyen du reactif Nadi. C.R. Académie des Sciences Paris série D 258: 1338 -1340.

Dutra VF, Garcia CP. 2013a. Three new species of Mimosa (Leguminosae) from Minas Gerais, Brazil. Systematic Botany 38: 398-405.

Dutra VF, Garcia CP. 2013b. Two new species and one new variety of Mimosa sect. Habbasia (Leguminosae: Mimosoideae) from Central Brazil. Kew Bulletin 68: 163-171.

Fahn A. 1979. Secretory tissues in plants. London, Academic Press.

Flora do Brasil 2020 (under construction). 2018. Mimosa. Jardim Botânico do Rio de Janeiro. http://floradobrasil.jbrj.gov.br/reflora/ floradobrasil/FB23084. 20 Nov. 2018.

Fortes AB. 1959. Geografia física do Rio Grande do Sul. Porto Alegre, Globo. Ganter P, Jollés G. 1969. Histologie normale et pathologique. Paris, Gauthier-Villars.

Grings M, Krapovickas A, Boldrini II. 2011. A new species of Pavonia (Malvaceae) from Southern Brazil. Systematic Botany 36: 419-423.

Grohar M, Rosenfeldt S, Morales M. 2016. Leaflet trichome micromorphology in the Dolentes-Brevipedes taxonomic complex (Mimosa L., Mimosoideae). Turkish Journal of Botany 40: 45-58.

Johansen DA. 1940. Plant microtechnique. New York, McGraw- Hill Book.

Mace ME, Howell CR. 1974. Histochemistry and identifications of condensed tannin precursor in roots of cotton seedlings. Canadian Journal of Botany 52: 2423-2426.
Machado PFS, Marchiori JNC. 2017. Anatomia dos lenhos de Mimosa intricata Benth. e Mimosa taimbensis Burkart (Fabaceae). Balduinia 57: 19-29.

Morales M, Santos-Silva J, Ribas OS. 2013. A new species of Mimosa sect. Mimosa (Leguminosae, Mimosoideae) from Southern Brazil. Brittonia 65: 148-153.

Morales M, Fortunato RH. 2010. Novedades taxonómicas y nomenclaturales en Mimosa L. subser. Mimosa (Leguminosae) para Sudamérica Austral. Candollea 65: 170-84.

Pearse AGE. 1980. Histochemistry theoretical and applied. 4th. edn. London, Churchill Livingstone

Santos-Silva J, Tozzi AMGA. 2012. Mimosa foreroana (Leguminosae, Mimosoideae), a new species from Nariño, Colombia. Systematic Botany 37: 437-441.

Santos-Silva J, Tozzi AMGA, Simon MF, Urquiza NG, Morales M. 2013. Evolution of trichome morphology in Mimosa (LeguminosaeMimosoideae). Phytotaxa 119: 1-20.

Simon MF, Grether R, Queiroz LP, Särkinen TE, Dutra VF, Hughes CE. 2011. The evolutionary history of Mimosa (Leguminosae): toward a phylogeny of the sensitive plants. American Journal of Botany 98: 1201-1221.

Svendsen AB, Verpoort R. 1983. Chromatography of alkaloids. New York, Elsevier Scientific Publishing Company.

Thiers B. [continuously updated]. 2019. Index Herbariorum: A global directory of public herbaria and associated staff. New York, New York Botanical Garden's Virtual Herbarium. http://sweetgum.nybg. org/science/ih/. 20 Nov. 2018.

Vidal BC. 1977. Acid glycosaminoglycans and endochondral ossification: microespectrophotometric evaluation and macromolecular orientation. Cellular and Molecular Biology 22: 45-64. 